\title{
Weed Management in Spring Planted Cereals with Mesotrione
}

\author{
Nader Soltani, Christy Shropshire, Todd Cowan, Peter H. Sikkema
}

University of Guelph Ridgetown Campus, Ridgetown, Canada.

Email: soltanin@uoguelph.ca

Received October $16^{\text {th }}, 2013$; revised December $18^{\text {th }}, 2013$; accepted January $7^{\text {th }}, 2014$

Copyright (c) 2014 Nader Soltani et al. This is an open access article distributed under the Creative Commons Attribution License, which permits unrestricted use, distribution, and reproduction in any medium, provided the original work is properly cited. In accordance of the Creative Commons Attribution License all Copyrights (c) 2014 are reserved for SCIRP and the owner of the intellectual property Nader Soltani et al. All Copyright (C) 2014 are guarded by law and by SCIRP as a guardian.

\section{ABSTRACT}

There is little information on the efficacy of mesotrione for the control of broadleaved weeds in spring planted cereals under Ontario environmental conditions. A total of eight studies were conducted in Ontario over a twoyear period (2010 to 2011) to evaluate cereal tolerance and weed control efficacy of mesotrione applied preemergence (PRE) at 25, 50, 100, 140, and $280 \mathrm{~g}$ a ha $^{-1}$ in spring planted barley, durum wheat, oats, and wheat. Mesotrione, applied preemergence at the rates evaluated, caused no injury in either year in spring planted barley, durum wheat, oats, or wheat evaluated at 1, 2 and 4 week after emergence (WAE). The predicted mesotrione rate required to give adequate control of AMBEL, CHEAL, POLCO and SINAR was generally greater than 280 $\mathrm{g}_{\text {ai }} \mathrm{ha}^{-1}$. The average yield of the weedy check was $81 \%$ of the weed-free check. According to the exponential to maximum regression, the mesotrione rates required to give $90 \%, 95 \%$ and $98 \%$ of the weed-free check were 15 , 30 and $45 \mathrm{~g}_{\text {ai }} \mathrm{ha}^{-1}$, respectively. To provide yield equivalent to the standard treatment of bromoxynil/MCPA, $36 \mathrm{~g}$ ai ha ${ }^{-1}$ of mesotrione was needed. Based on these results, mesotrione applied preemergence at 25, 50, 100, 140, and $280 \mathrm{~g}_{\text {ai }} \mathrm{ha}^{-1}$ can be safely used in spring planted barley, durum wheat, oats, and wheat. However, greater than $280 \mathrm{~g}_{\text {ai }} \mathrm{ha}^{-1}$ of mesotrione was needed to adequately control AMBEL, CHEAL, POLCO and SINAR.

\section{KEYWORDS}

\section{Barley; Durum Wheat; Height; Herbicide Sensitivity; Oats; Tolerance; Yield; Wheat}

\section{Introduction}

In recent years, cereal production has increased in Ontario because of new, improved cultivars, reduced-till production systems and increased prices. Cereals including spring planted barley (Hordeum vulgare L.), durum wheat [Triticum turgidum subsp. durum (Desf.) Husn.], oats (Avena sativa L.) and wheat (Triticum aestivum L.) are also ideal crops to include in the rotation as they help to maintain soil structure and break weed cycles. One of the most significant aspects of spring cereal production is weed management [1]. Herbicides registered in cereals have not changed appreciably in the past 20 years in Ontario [2]. Postemergence (POST) herbicides such as 2,4-D, MCPA, bromoxynil/MCPA, dicamba/MCPA/ mecoprop, dichlorprop/2,4-D and thifensulfuron-methyl/ tribenuron-methyl are still being used, either alone or in combination for the control of broadleaved weeds in cereals [2,3]. There have been reports of crop sensitivity in cereals with some of these herbicides in cereals [4]. Currently, there are no soil applied residual herbicides available for annual grass and broadleaved weed control in spring planted barley, durum wheat, oats and wheat in Ontario. More research is needed to determine tolerance and weed control efficacy of spring planted cereals to recently developed herbicides with a novel mode of action.

Mesotrione is a triketone that inhibits the p-hydroxyphenylpyruvate dioxygenase (HPPD) enzyme responsible for catalyzing the conversion of tyrosine to plastoquinone and $\alpha$-tycopherol [5-7]. Mesotrione can be absorbed by the germinating seed, emerging root and shoot and is translocated in the xylem and phloem [8]. Mesotrione controls broadleaved weeds including Amaranthus 
retroflexus L. (redroot pigweed), Chenopodium album L. (common lamb's-quarters), Xanthium strumarium L. (common cocklebur), Abutilon theophrasti Medic. (velvetleaf), Polygonum persicaria Mill. (ladysthumb), and Ambrosia trifida L. (giant ragweed) and some grass species including Digitaria sanguinalis (L.) Scop. (large crabgrass) and Echinochloa crus-galli (L.) Beauv. (barnyardgrass) [8-10]. Injury symptoms with mesotrione in susceptible plants include bleaching of meristemic tissue followed by growth cessation and necrosis within 3-5 days $[5,8]$. Mesotrione has a favorable environmental and toxicological profile with relatively low toxicity to mammals, birds and aquatic species [10].

There is limited information published on the sensitivity of spring planted barley, durum wheat, oats, and wheat to mesotrione and the efficacy of mesotrione for the control of broadleaved weeds in spring seeded cereals under Ontario environmental conditions. Mesotrione can provide growers with an additional herbicide option to provide season-long control of broadleaved weeds including acetolactate synthase and triazine-resistant biotypes in spring planted barley, durum wheat, oats, and wheat.

The objectives of this research were to determine the tolerance of spring planted barley, durum wheat, oats, and wheat to mesotrione applied preemergence (PRE) at $25,50,100,140$ and $280 \mathrm{~g}$ ai ha ${ }^{-1}$ and to evaluate the efficacy of mesotrione on common broadleaved weeds in Ontario.

\section{Materials and Methods}

\subsection{Study Establishment}

Field studies were conducted at the Huron Research Station, Exeter, Ontario in 2010 and 2011. The soil for study sites was a Brookston clay loam. Seedbed preparation consisted of moldboard plowing in the autumn followed by two passes with a cultivator with rolling basket harrows in the spring.

There were four trials established in each year (one for each cereal type: barley, durum wheat, oats, and wheat) adjacent to each other as a randomized complete block design with four replications. Treatments included a weed free control, a standard treatment of bromoxynil/MCPA applied POST at $560 \mathrm{~g}^{\text {ai }} \mathrm{ha}^{-1}$ and mesotrione applied PRE at 25, 50, 100, 140, and $280 \mathrm{~g}_{\text {ai }} \mathrm{ha}^{-1}$. Plots for each trial were $2 \mathrm{~m}$ wide and $10 \mathrm{~m}$ long. Spring planted barley "Bornholm", durum wheat "Hallmark", oats "Sherwood" and wheat "Hobson" were seeded with a double disc drill at $140 \mathrm{~kg} \mathrm{ha}^{-1}$ in rows spaced $17.5 \mathrm{~cm}$ apart at a depth of $4 \mathrm{~cm}$ in late April.

Mesotrione was applied within 3 days of seeding with a $\mathrm{CO}_{2}$ pressurized backpack sprayer calibrated to deliver $200 \mathrm{~L} \mathrm{ha}^{-1}$ at $240 \mathrm{kPa}$. The boom was $1.5 \mathrm{~m}$ long with four Hypro ULD120-02 nozzle tips (Hypro, New Brigh- ton, MN, USA) spaced $50 \mathrm{~cm}$ apart. Bromoxynil/MCPA was applied POST when the spring cereals were in the 2 - 5 leaf stage. The non-treated control plots were kept weed-free by hand weeding.

\subsection{Data Collection}

Visible crop injury was rated on a scale of 0 to $100 \%$ (0 $=$ no visible injury, and $100=$ plant death) at 1,2 , and 4 weeks after emergence (WAE). Weed control was evaluated on a scale of 0 to $100 \%$ ( $0=$ no weed control, and $100=$ complete weed control) 4 and 8 WAE. Weed density and biomass by species were recorded from two half-meter quadrats in each plot at 8 WAE. All cereals were harvested in late July using a plot combine and yields were adjusted to $14.8 \%, 14.5 \%, 13.5 \%$, and $14.0 \%$ moisture for barley, durum wheat, oats and wheat, respectively.

\subsection{Statistical Analysis}

Data were analyzed using non-linear regression (PROC NLIN) in SAS 9.2 [11]. The weed-free control and the bromoxynil/MCPA treatment were not included in regression analysis. Weed density and dry weight were converted to a percent of the weedy control and yield was converted to a percent of the weed-free control prior to analysis. The PROC MIXED procedure of SAS was used to determine if environments (comprising cereal types and years) could be combined for regression analysis. If the environment by mesotrione rate interaction was not significant, there was deemed to be no difference in response among cereal type and year combinations and environments were analyzed together.

All parameters were regressed against mesotrione rate, designated as RATE in the equations. The equation used for percent weed control (dose-response), using a four parameter log-logistic model was:

$$
Y=C+(D-C) /\left(1+\exp \left[-b\left(\ln R A T E-\ln I_{50}\right)\right]\right)
$$

where $C$ is the lower asymptote, $D$ is the upper asymptote, $b$ is the slope and $I_{50}$ is the dose which gives a response halfway between $C$ and $D$.

The equation used for the one instance where dose-response did not fit the weed control data (CHEAL for 2011, 4 WAE), and for yield (exponential to maximum) was:

$$
Y=f+g *(\exp [-h * R A T E])
$$

where $f$ is the upper asymptote, $g$ is the magnitude of the response and $h$ is the slope of the response.

The equation used for percent density and dry weight (dose-response), using a four parameter log-logistic model was:

$$
Y=C+(D-C) /\left(1+\exp \left[b\left(\ln R A T E-\ln I_{50}\right)\right]\right)
$$


where parameters are identical to Equation (2), the only difference is that $b$ is positive to reflect the change in direction of the response.

In cases where the dose-response equation did not fit density and dry weight, an inverse exponential equation was used:

$$
Y=i+j *(\exp [-k * R A T E])
$$

where $i$ is the lower asymptote, $j$ is the magnitude of the response and $k$ is the slope of the response.

For POLCO density and dry weight, a linear equation best fit the data:

$$
Y=a+m * R A T E
$$

where $a$ is the intercept and $m$ is the slope.

\section{Results and Discussion}

Regression equations were used to calculate predicted mesotrione rates $\left(\mathrm{g} \mathrm{ai} \mathrm{ha}^{-1}\right.$ ) required to give $50 \%, 80 \%$ and $95 \%$ percent control of weed species or a $50 \%, 80 \%$ and $95 \%$ reduction in percent weed density or dry weight $\left(R_{50}, R_{80}\right.$ and $\left.R_{95}\right)$, or the rate which gave $90 \%, 95 \%$ and $98 \%$ yield of the weed-free control $\left(R_{90}, R_{95}, R_{98}\right)$. The predicted rate of mesotrione $\left(\mathrm{R}_{\mathrm{eq}}\right)$ that gave the equivalent control (or reduction in density, dry weight, or yield) to the bromoxynil/MCPA (standard) treatment for a given weed species or the crop was also calculated. If any rate was predicted to be higher than $280 \mathrm{~g}_{\text {ai ha }}{ }^{-1}$, it was simply expressed as ">280" since it would be improper to extrapolate outside the range of rates evaluated in these experiments.

\subsection{Crop Injury}

There was no injury in either year for spring planted barley, durum wheat, oats, and wheat to mesotrione applied preemergence at $25,50,100,140$, and $280 \mathrm{~g}_{\text {ai ha }}{ }^{-1}$ at 1 , 2 and 4 WAE (data not shown). The level of injury observed in this study is similar to those found with currently used POST herbicides in Ontario such as 2,4-D, MCPA, dichlorprop plus 2,4-D, and bromoxynil plus MCPA [2,4,12].

\subsection{Visible Weed Control}

The primary weeds present at the study sites included Ambrosia artemisiifolia (AMBEL), Chenopodium album (CHEAL), Polygonum convolvulus (POLCO) and Sinapsis arvensis (SINAR).

The predicted mesotrione rates required to give $50 \%$, $80 \%$ and $95 \%$ control of AMBEL were 88, 242 and $>280$ g ai ha ${ }^{-1}$ at 4 WAE and 55, 184 and $>280$ g ai ha $^{-1}$ at 8 WAE, respectively (Table 1 ). To provide AMBEL control equivalent to the standard treatment of bromox-
ynil/MCPA, 201 and $>280 \mathrm{~g}$ ai ha ${ }^{-1}$ of mesotrione was needed at 4 and $8 \mathrm{WAE}$, respectively (Table 1).

The mesotrione rates required to give $50 \%, 80 \%$ and 95\% control of CHEAL were 11 - 45, 26 - 85 and 46- > $280 \mathrm{~g}_{\text {ai ha }}{ }^{-1}$ at $4 \mathrm{WAE}$ and 35,72 and $>280 \mathrm{~g}_{\text {ai ha }}{ }^{-1}$ at 8 WAE, respectively (Table 1). To provide CHEAL control equivalent to the standard treatment of bromoxynil/MCPA, $45-77$ and $>280 \mathrm{~g}^{\text {ai }} \mathrm{ha}^{-1}$ of mesotrione was needed at 4 and $8 \mathrm{WAE}$, respectively (Table 1 ).

The mesotrione rates required to give $50 \%, 80 \%$ and $95 \%$ control of POLCO were 97, $>280$ and $>280$ g ai ha $^{-1}$ at 4 WAE and 53, 249 and $>280 \mathrm{~g}_{\text {ai ha }}{ }^{-1}$ at 8 WAE, respectively (Table 1). To provide POLCO control equivalent to the standard treatment of bromoxynil/ MCPA, > $280 \mathrm{~g}$ ai ha $^{-1}$ of mesotrione was needed at 4 and 8 WAE (Table 1).

The mesotrione rates required to give $50 \%, 80 \%$ and $95 \%$ control of SINAR were 34, 107 and $>280 \mathrm{~g}$ ai ha $^{-1}$ at $4 \mathrm{WAE}$ and 31, 73 and $192 \mathrm{~g}^{\mathrm{ai}} \mathrm{ha}^{-1}$ at $8 \mathrm{WAE}$, respectively (Table 1 ). To provide SINAR control equivalent to the standard treatment of bromoxynil/MCPA, 76 and $>280 \mathrm{~g}_{\text {ai }} \mathrm{ha}^{-1}$ of mesotrione was needed at 4 and 8 WAE, respectively (Table 1).

\subsection{Weed Density and Biomass}

The predicted mesotrione rates required to give 50, 80 and $95 \%$ reduction were $246,>280$ and $>280 \mathrm{~g}$ ai ha $^{-1}$ for AMBEL density and 183, $>280$ and $>280 \mathrm{~g}_{\text {ai }} \mathrm{ha}^{-1}$ for AMBEL biomass, respectively (Table 2). To provide AMBEL density and biomass equivalent to the standard treatment of bromoxynil/MCPA, greater than $280 \mathrm{~g}$ ai $\mathrm{ha}^{-1}$ of mesotrione was needed at 8 WAE (Table 2).

The predicted mesotrione rates required to give 50,80 and 95\% reduction were 41 - 66, 71 - 264 and 131- > 280 g ai ha ${ }^{-1}$ for CHEAL density and 40, 101 and $>280$ g ai $\mathrm{ha}^{-1}$ for CHEAL biomass, respectively (Table 2). To provide CHEAL density and biomass equivalent to the standard treatment of bromoxynil/MCPA, $145-260$ and $>280 \mathrm{~g}_{\text {ai }} \mathrm{ha}^{-1}$ of mesotrione was needed, respectively (Table 2).

The predicted mesotrione rates required to give 50, 80 and $95 \%$ reduction were 46,177 and $>280 \mathrm{~g}$ ai ha $^{-1}$ for SINAR density and 17, 40 and $84 \mathrm{~g}^{\text {ai }} \mathrm{ha}^{-1}$ for SINAR biomass, respectively (Table 2). To provide SINAR density and biomass equivalent to the standard treatment of bromoxynil/MCPA, greater than $280 \mathrm{~g}$ ai ha ${ }^{-1}$ of mesotrione was needed at $8 \mathrm{WAE}$ (Table 2).

The predicted mesotrione rates required to give 50,80 and $95 \%$ reduction was $>280 \mathrm{~g}_{\text {ai }} \mathrm{ha}^{-1}$ for POLCO density and 216 to $>280 \mathrm{~g}$ ai ha ${ }^{-1}$ for POLCO biomass (Table 2). To provide POLCO density and biomass equivalent to the standard treatment of bromoxynil/MCPA, greater than $280 \mathrm{~g}$ ai ha ${ }^{-1}$ of mesotrione was 
Table 1. Regression parameter estimates and predicted mesotrione rates from dose-response and exponential to maximum models of visual weed control 4 and 8 WAE $^{\mathrm{a}}$.

\begin{tabular}{|c|c|c|c|c|c|c|c|c|c|c|c|c|c|c|}
\hline \multirow[b]{2}{*}{ Weed } & \multirow[b]{2}{*}{ WAE } & \multirow[b]{2}{*}{ Year } & \multicolumn{8}{|c|}{ Parameter estimates $^{\mathrm{b}}( \pm \mathrm{SE})$} & \multicolumn{4}{|c|}{ Predicted mesotrione rate $^{\mathrm{c}}$} \\
\hline & & & \multicolumn{2}{|c|}{$C$} & \multicolumn{2}{|c|}{ D } & \multicolumn{2}{|c|}{$b$} & \multicolumn{2}{|c|}{$I_{50}$} & $\mathbf{R}_{50}$ & $\mathbf{R}_{80}$ & $\mathbf{R}_{95}$ & $\mathbf{R}_{\mathrm{eq}}$ \\
\hline \multicolumn{3}{|c|}{ Dose-response } & \multicolumn{4}{|c|}{$\%$} & & & & & & \\
\hline AMBEL & 4 & & 0 & $(0)$ & 93 & (7) & 1.6 & $(0.2)$ & 80 & (10) & 88 & 242 & $>280$ & 201 \\
\hline AMBEL & 8 & & 0 & (0) & 92 & (7) & 1.4 & $(0.2)$ & 49 & (7) & 55 & 184 & $>280$ & $>280$ \\
\hline CHEAL & 4 & 2010 & 0 & $(0)$ & 92 & (4) & 2.7 & $(0.5)$ & 42 & (3) & 45 & 85 & $>280$ & 45 \\
\hline CHEAL & 8 & & 0.10 & (5.6) & 91 & (5) & 2.5 & $(0.7)$ & 33 & (4) & 35 & 72 & $>280$ & $>280$ \\
\hline POLCO & 4 & & 0.49 & $(5.7)$ & 100 & (0) & 1.3 & $(0.2)$ & 98 & (15) & 97 & $>280$ & $>280$ & $>280$ \\
\hline POLCO & 8 & & 0 & $(0)$ & 86 & (12) & 1.5 & $(0.6)$ & 42 & (11) & 53 & 249 & $>280$ & $>280$ \\
\hline SINAR & 4 & & 0.23 & $(2.1)$ & 100 & $(0)$ & 1.2 & $(0.1)$ & 34 & (2) & 34 & 107 & $>280$ & 76 \\
\hline SINAR & 8 & & 0.14 & (3.0) & 100 & (0) & 1.6 & $(0.2)$ & 31 & (2) & 31 & 73 & 192 & $>280$ \\
\hline \multicolumn{3}{|c|}{ Exponential to maximum } & \multicolumn{2}{|c|}{$f$} & \multicolumn{2}{|c|}{$g$} & \multicolumn{2}{|r|}{$h$} & & & & & & \\
\hline CHEAL & 4 & 2011 & 101 & (3) & 101 & (7) & 0.061 & $(0.012)$ & & & 11 & 26 & 46 & 77 \\
\hline
\end{tabular}

a Abbreviations: AMBEL, common ragweed; CHEAL, common lamb’s quarters; POLCO, wild buckwheat; SINAR, wild mustard; WAE, weeks after spring grain emergence; ${ }^{b}$ Dose response parameters (Eq. 1): $b$, slope; $C$, lower asymptote; $D$, upper asymptote; $I_{50}$, rate required for $50 \%$ response. Inverse exponential parameters (Eq. 2): $f$, upper asymptote; $g$, magnitude of response; $h$, slope of response; ${ }^{c} \mathrm{R}_{50}, \mathrm{R}_{80}, \mathrm{R}_{95}$ and $\mathrm{R}_{\mathrm{eq}}$ are the rates required to give weed control of $50 \%$, $80 \%, 95 \%$ and equivalent to bromoxynil/MCPA, respectively, for a given weed species.

Table 2. Regression parameter estimates and predicted mesotrione rates from dose-response, inverse exponential and linear models of percent weed density and dry weight 8 WAE ${ }^{\mathrm{a}}$.

\begin{tabular}{|c|c|c|c|c|c|c|c|c|c|c|c|c|c|c|}
\hline \multirow[b]{2}{*}{ Weed } & \multirow[b]{2}{*}{ Variable } & \multirow[b]{2}{*}{ Year } & \multicolumn{8}{|c|}{ Parameter estimates $^{\mathrm{b}}( \pm \mathrm{SE})$} & \multicolumn{4}{|c|}{ Predicted mesotrione rate $^{c}$} \\
\hline & & & & & & & & $b$ & & $I_{50}$ & $\mathbf{R}_{50}$ & $\mathbf{R}_{\mathbf{8 0}}$ & $\mathbf{R}_{\mathbf{9 5}}$ & $\mathbf{R}_{\mathbf{e q}}$ \\
\hline \multicolumn{3}{|c|}{ Dose-response } & \multicolumn{4}{|c|}{$\%$} & & & \multicolumn{6}{|c|}{ g ai ha ${ }^{-1}$} \\
\hline CHEAL & Dens & 2010 & 0 & $(0)$ & 99 & (13) & 2.5 & $(1.1)$ & 41 & (9) & 41 & 71 & 131 & 145 \\
\hline CHEAL & Dens & 2011 & 0 & (0) & 100 & (20) & 1.0 & $(0.6)$ & 65 & (41) & 66 & 264 & $>280$ & 260 \\
\hline CHEAL & Drywt & & 0 & (0) & 99 & (11) & 1.5 & $(0.5)$ & 41 & (11) & 40 & 101 & $>280$ & $>280$ \\
\hline SINAR & Dens & & 0 & (0) & 99 & $(16)$ & 1.0 & $(0.5)$ & 47 & (24) & 46 & 177 & $>280$ & $>280$ \\
\hline \multicolumn{3}{|c|}{ Inverse exponential } & \multicolumn{2}{|c|}{$i$} & \multicolumn{2}{|c|}{$j$} & \multicolumn{2}{|r|}{$k$} & & & & & & \\
\hline AMBEL & Dens & & 0 & (0) & 115 & (12) & 0.0034 & $(0.0012)$ & & & 246 & $>280$ & $>280$ & $>280$ \\
\hline AMBEL & Drywt & & 0 & $(0)$ & 123 & (19) & 0.0049 & $(0.0022)$ & & & 183 & $>280$ & $>280$ & $>280$ \\
\hline \multirow[t]{2}{*}{ SINAR } & Drywt & & 2.4 & (2.6) & 97 & (5) & 0.0430 & $(0.0054)$ & & & 17 & 40 & 84 & $>280$ \\
\hline & Linear & & \multicolumn{2}{|c|}{$a$} & \multicolumn{2}{|c|}{$m$} & & & & & & & & \\
\hline POLCO & Dens & & 126 & (28) & -0.12 & $(0.20)$ & & & & & $>280$ & $>280$ & $>280$ & $>280$ \\
\hline POLCO & Drywt & & 96 & (15) & -0.21 & $(0.11)$ & & & & & 216 & $>280$ & $>280$ & $>280$ \\
\hline
\end{tabular}

a Abbreviations: AMBEL, common ragweed; CHEAL, common lamb’s quarters; Dens, percent weed density; Drywt, percent weed dry weight; POLCO, wild buckwheat; SINAR, wild mustard; WAE, weeks after spring cereal emergence; 'Dose response parameters (Equation (3)): $b$, slope; $C$, lower asymptote; $D$, upper asymptote; $I_{50}$, rate required for $50 \%$ response. Exponential to maximum parameters (Equation (4)): $i$, lower asymptote; $j$, magnitude of response; $k$, slope of response. Linear parameters (Equation (5)): $a$, intercept; $m$, slope; ${ }^{\mathrm{c}} \mathrm{R}_{50}, \mathrm{R}_{80}, \mathrm{R}_{95}$ and $\mathrm{R}_{\mathrm{eq}}$ are the rates required to give a $50 \%$, $80 \%$, $95 \%$ and equivalent to bromoxynil/MCPA reduction in percent density or dry weight, respectively, for a given weed species.

needed at 8 WAE (Table 2).

\subsection{Yield}

The average yield of the weedy control was $81 \%$ of the weed-free control. According to the exponential to maximum regression, the mesotrione rates required to give 90,95 and $98 \%$ of the weed-free control were 15, 30 and $45 \mathrm{~g}$ ai ha ${ }^{-1}$, respectively. To provide yield equivalent to the standard treatment of bromoxynil/MCPA, $36 \mathrm{~g}$ ai ha ${ }^{-1}$ of mesotrione was needed (data not shown). In other studies, there was no difference in yield of barley, oats and wheat to the PRE application of herbicides such as saflufenacil [1] and mesotrione [13] which is similar to the yield response of cereals to currently used POST herbicides such as 2,4-D amine, bromoxynil plus MCPA, and dichlorprop plus 2,4-D [2,4]. Mesotrione applied POST reduced the yield of spring wheat as much as $14 \%$ but had no adverse effect on the yield of spring barley or spring oats in another study [13]. Saflufenacil applied POST also reduced yield of spring barley $24 \%$ and spring wheat $13 \%$ but had no effect on the yield of spring oats [1]. Other studies have shown cereal yield reduction of as much as $39 \%$ with dicamba applied POST alone, or in combination with other herbicides such as 2,3,6-TBA, 
MCPA or mecoprop [1,3,4,14-17].

\section{Conclusion}

Based on these results, mesotrione applied preemergence at $25,50,100,140$, and $280 \mathrm{~g}_{\text {ai }} \mathrm{ha}^{-1}$ can be safely used in spring planted barley, durum wheat, oats, and wheat. The predicted mesotrione rate required to give adequate control of AMBEL, CHEAL, POLCO and SINAR was generally greater than $280 \mathrm{~g}$ ai ha ${ }^{-1}$. Further studies are needed to evaluate mesotione applied preemergence at rates greater than $280 \mathrm{~g}$ ai ha ${ }^{-1}$ for the control of broadleaved weeds in spring planted cereals.

\section{Acknowledgements}

Funding for this project was provided in part by the Grain Farmers of Ontario.

\section{REFERENCES}

[1] P. H. Sikkema, C. Shropshire and N. Soltani, "Tolerance of Spring Barley (Hordeum vulgare), Oats (Avena sativa) and Wheat (Triticum aestivum L.) to Saflufenacil," Crop Protection, Vol. 27, 2008, pp. 1495-1497. http://dx.doi.org/10.1016/j.cropro.2008.07.009

[2] Ontario Ministry of Agriculture, Food, and Rural Affairs, "Guide to Weed Control," Ontario Ministry of Agriculture, Food, and Rural Affairs, Toronto, 2013.

[3] J. A. Ivany, H. G. Nass and J. B. Sanderson, "Effect of Time of Application of Herbicides on Yield of Three Winter Wheat Cultivars," Canadian Journal of Plant Science, Vol. 70, No. 3, 1990, pp. 605-609. http://dx.doi.org/10.4141/cjps90-076

[4] P. H. Sikkema, L. Brown, C. Shropshire and N. Soltani, "Responses of Three Types of Winter Wheat (Triticum aestivum L.) to Spring-Applied Post-Emergence Herbicides," Crop Protection, Vol. 26, 2007, pp. 715-720. http://dx.doi.org/10.1016/j.cropro.2006.06.010

[5] J. A. Abendroth, A. R. Martin and F. W. Roeth, "Plant Response to Combinations of Mesotrione and Photosystem II Inhibitors," Weed Technology, Vol. 20, No. 1, 2006, pp. 267-274.

http://dx.doi.org/10.1614/WT-05-020R.1

[6] F. D Hess, "Review: Light-Dependent Herbicides: An Overview," Weed Science, Vol. 48, No. 2, 2000, pp. 160170.

http://dx.doi.org/10.1614/0043-1745(2000)048[0160:LD HAO]2.0.CO;2

\section{Abbreviations}

AMBEL: common ragweed;

CHEAL: common lamb's quarters;
[7] G. Mitchell, D. W. Bartlett, T. E. M. Fraser, T. R. Hawkes, D. C. Holt, J. K Townson and R. A. Wichert, "Mesotrione: A New Selective Herbicide for Use in Maize," Pest Management Science, Vol. 57, No. 2, 2001, pp. 120-128. http://dx.doi.org/10.1002/1526-4998(200102)57:2<120:: AID-PS254>3.0.CO;2-E

[8] S. A. Senseman, "Herbicide Handbook," 9th Edition, Weed Science Society of America, Champaign, 2007, 458 p.

[9] G. R. Armel, H. P. Wilson, R. R. Richardson and T. E. Hines, "Mesotrione Combinations in No-Till Corn (Zea mays)," Weed Technology, Vol. 17, 2003, pp. 111-116. http://dx.doi.org/10.1614/0890-037X(2003)017[0111:MC INTCl2.0.CO;2

[10] J. O'Sullivan, J. Zandstra and P. Sikkema, "Sweet Corn (Zea mays) Cultivar Sensitivity to Mesotrione," Weed Technology, Vol. 16, 2002, pp. 421-425. http://dx.doi.org/10.1614/0890-037X(2002)016[0421:SC ZMCS12.0.CO;2

[11] Statistical Analysis Systems, "The SAS System," Version 9.2. Cary, Statistical Analysis Systems Institute, 2008.

[12] N. Soltani, C. Shropshire and P. H. Sikkema, "Responses of Winter Wheat (Triticum aestivum L.) to Autumn Applied Post-Emergence Herbicides," Crop Protection, Vol. 25, 2006, pp. 346-349.

http://dx.doi.org/10.1016/j.cropro.2005.05.012

[13] N. Soltani, C. Shropshire and P. H. Sikkema, "Response of Spring Barley (Hordeum Vulgare L.), Oats (Avena sativa L.) and Wheat (Triticum aestivum L.) to Mesotrione," Crop Protection, Vol. 3, 2011, pp. 849-853. http://dx.doi.org/10.1016/j.cropro.2011.03.023

[14] D. A. Martin, S. D. Miller and H. P. Alley, "Winter Wheat (Triticum aestivum) Response to Herbicides Applied at Three Growth Stages,” Weed Technology, Vol. 3, 1989, pp. 90-94.

[15] M. J. Rinella, J. J. Kells and R. W. Ward, "Response of 'Wakefield' Winter Wheat (Triticum aestivum) to Dicamba," Weed Technology, Vol. 15, 2001, pp. 523-552. http://dx.doi.org/10.1614/0890-037X(2001)015[0523:RO WWWT]2.0.CO;2

[16] D. R. Tottman, "The Effects of a Dicamba Herbicide Mixture on the Grain Yield Components of Winter Wheat," Weed Research, Vol. 18, 1978, pp. 335-339. http://dx.doi.org/10.1111/j.1365-3180.1978.tb01170.x

[17] D. R. Tottman, "The Effects of Broad-Leaved Weed Herbicides Applied to Cereal Crops at Different Growth Stages," Aspects of Applied Biology I: Broad-Leaved Weeds and Their Control in Cereals, University of Warwick, England, 1982, pp. 201-210.

POLCO: wild buckwheat;

SINAR: wild mustard;

WAE: weeks after spring grain emergence. 